fournal of Medical Genetics (1975). 12, 378.

\title{
Differences in human $\mathrm{X}$ isochromosomes
}

\author{
J. H. PRIEST, R. D. BLACKSTON, K.-S. AU, and S. L. RAY \\ From the Division of Medical Genetics, Department of Pediatrics, Emory University School of Medicine, \\ Atlanta, Georgia 30322, USA
}

Summary. In this paper we describe two types of $\mathrm{i}(\mathrm{Xq})$, in three patients. A classification is proposed for at least seven different types of human $\mathrm{i}(\mathrm{Xq})$ s or $\mathrm{X}$ longarm duplications described by banding in the literature. Type 1 reported here and also in the literature may be the most common. It consists of a single visible centromere, metacentric, length similar to number 3, G-banding interpreted as $\mathbf{i}(\mathrm{X})$ (qter $\rightarrow$ cen $\rightarrow$ qter), one $\mathrm{C}$-band like a normal $X$. Type 2 reported here may not have a counterpart in the literature; it exhibits a single visible centromere, submetacentric, length similar to number 3, extra G- and C-bands in region ql.

The classification summarized in this paper implies that different breakpoints are involved in the production of human X long-arm isochromosomes or duplications. Some include duplications of short arm. Morphological differences in $\mathrm{i}(\mathrm{Xq})$ s will complicate their use for studying the effect of X chromosome structure on phenotype, unless differences are defined clearly. It seems important to resolve the question of whether these reported abnormal $\mathrm{X}$ chromosomes involve rearrangements between the same or two $\mathrm{X}$ chromosomes.

We also report $\mathrm{X}$ chromosome defects in three generations of a family; both the mother and maternal grandmother of one $45, \mathrm{X}, \mathrm{i}(\mathrm{Xq}) / 45, \mathrm{X}$ patient are themselves mosaics for $45, \mathrm{X} / 46, \mathrm{XX} / 46, \mathrm{X}, \mathrm{r}(\mathrm{X})$. This family suggests that familial predisposition to $\mathrm{X}$ chromosome abnormality includes isochromosome formation, as well as ring formation and mosaicism.

Isochromosomes or duplications for the long arm of the human $\mathrm{X}$ chromosome may show varying morphologies (de la Chapelle and Stenstrand, 1974; Ruthner and Golob, 1974a; Yanagisawa, 1974). Duplications of $X$ long and short arms resulting from attachment of $\mathrm{X}$ chromosomes or chromatids by long or short arms are now confirmed by banding studies (Distèche et al, 1972; van den Berghe et al, 1973b; de la Chapelle and Stenstrand, 1974; Kim et al, 1974; Ruthner and Golob, 1974b; Therman et al, 1974b). Differences in human $\mathrm{i}(\mathrm{Xq})$ s or $\mathrm{X}$ long- and short-arm duplications have important implications for understanding the mechanism of their formation and for their use in the study of the role of human $\mathrm{X}$ chromosomes in determining phenotype (Ferguson-Smith, 1965).

In this paper we describe additional cases of

Received 13 December 1974.
$\mathrm{i}(\mathrm{Xq})$ and propose an initial classification for $\overrightarrow{\vec{\partial}}$ different types in the literature since banding studies. Analysis of all the types of $\mathrm{X}$ long- and short-arm duplications may provide a unified:hypothesis for their formation.

We also report $X$ chromosome defects in three. generations of a family; both the mother and maternal grandmother of one $46, \mathrm{X}, \mathrm{i}(\mathrm{Xq}) / 45, \mathrm{X}_{\text {. }}$ mosaic patient are themselves mosaics for $45, \mathrm{X} / 3$ $46, X X / 46, X, r(X)$.

\section{Materials and methods}

Chromosome studies of peripheral blood were performed following standard $68-\mathrm{h}$ culture in the presence. of phytohaemagglutinin. Skin cultures were establishedN from biopsy of the right inner forearm (Priest, 1969) and N left gonad culture from biopsy at laparostomy.

All chromosome measurements were performed on $25 \%$ cells per individual, photographed following standarde 
TABLE I

CLINICAL AND LABORATORY FINDINGS

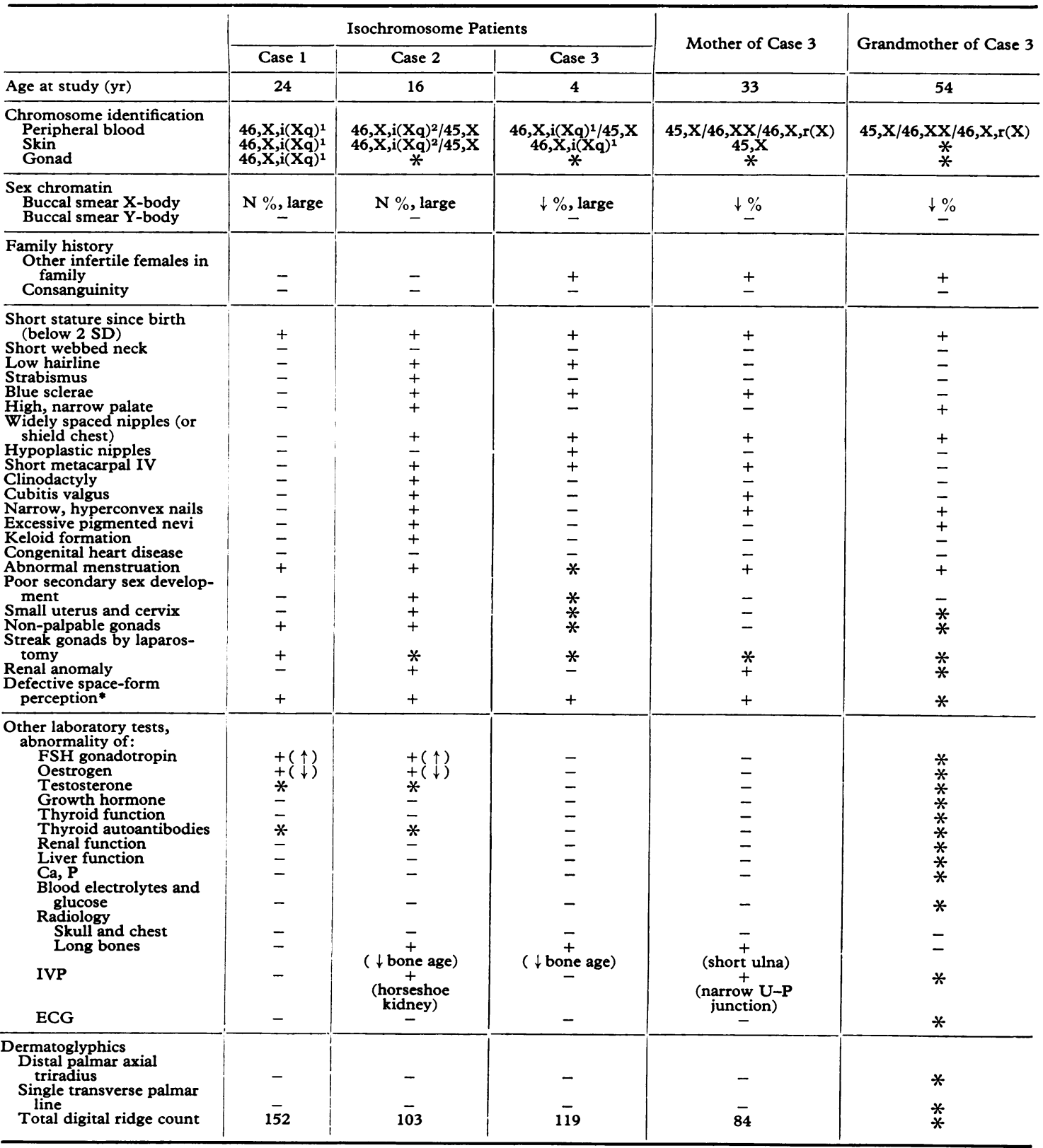

* Bender Visual Motor Gestalt Test or Beery Developmental Test of visual motor integration were used.

$+=$ present; $-=$ absent; $*=$ not determined; $\downarrow=$ decreased; $\uparrow=$ increased; $N=$ normal.

$\mathrm{i}(\mathrm{Xq})^{1}=$ Type $1 \mathrm{i}(\mathrm{Xq})$ described in the text (metacentric, size similar to number 3, G-banding like normal Xq, centromere and C-band

$\mathrm{i}(\mathrm{Xq})^{2}=$ Type $2 \mathrm{i}(\mathrm{Xq})$ described in the text (submetacentric, size similar to number 3, centromere like normal X, extra G- and C-band in region ql). 
Giemsa staining; $X$, number 3, and $i(X q)$ were measured from the projected $35 \mathrm{~mm}$ negatives after the metaphase had been re-stained with quinacrine dihydrochloride to identify individual chromosomes.

This Giemsa-quinacrine double staining technique used was as follows. The air-dried slide was stained in buffered Gurr Giemsa ( $\mathrm{pH} \mathrm{6.8)}$ for $5 \mathrm{~min}$. After the slide was studied it was dipped in xylene to remove the oil, blotted dry, and placed in $95 \%$ ethanol for $5 \mathrm{~min}$. It was then placed in $70 \%$ ethanol for $60 \mathrm{~min}$ to destain, air dried, and stained for $12 \mathrm{~min}$ in $0.5 \%$ aqueous solution of quinacrine dihydrochloride (Atebrin) which had either been freshly made or stored for not longer than $2 \mathrm{wk}$ in a refrigerator. The slide was then rinsed

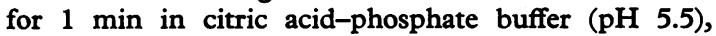
placed on a coverslip with the same buffer, and sealed (with nail polish) to prevent drying.

All light photomicroscopy was done with a Zeiss automatic $35 \mathrm{~mm}$ camera, all fluorescence photomicroscopy with a Leitz epifluorescence (Ploem) illuminator and a non-automatic $35 \mathrm{~mm}$ camera. The film used was Kodax panatomic X printed on No. 6 contrast paper.

C-banding, modified from the technique of Arrighi and Hsu (1971), was performed after identification of individual chromosomes in the same cell by a modified ASG-Giemsa technique (Sumner et al, 1971).

The Giemsa-C-banding double technique was performed as follows. The air-dried slide was placed in $2 \times S S C$ at $60^{\circ} \mathrm{C}$ for $90 \mathrm{~min}$ and stained in buffered Gurr Giemsa (pH 6.8) for 15 min. After study the slide was dipped in xylene to remove the oil, blotted dry, and placed in $95 \%$ ethanol for $5 \mathrm{~min}$ and then in $70 \%$ ethanol for $60 \mathrm{~min}$ to de-stain. The preparation was then air dried and placed in the following solutions: 200 $\mathrm{mM} \mathrm{HCl}$ for $15 \mathrm{~min}$; deionized $\mathrm{H}_{2} \mathrm{O}$ at $8-10^{\circ} \mathrm{C}$ for $5 \mathrm{~min}$; deionized $\mathrm{H}_{2} \mathrm{O}$ at $25^{\circ} \mathrm{C}$ (room temperature) for 5 min; saturated $\mathrm{Ba}(\mathrm{OH})_{2}$ for $30 \mathrm{~s}$; deionized $\mathrm{H}_{2} \mathrm{O}$ at 8-10 $0^{\circ} \mathrm{C}$ for $5 \mathrm{~min}$; deionized $\mathrm{H}_{2} \mathrm{O}$ at $25^{\circ} \mathrm{C}$ for $5 \mathrm{~min}$; $2 \mathrm{xSSC}\left(\mathrm{pH} \mathrm{7.0)}\right.$ at $60^{\circ} \mathrm{C}$ for $4 \mathrm{~h}$. The preparation was then rinsed in $70 \%$ ethanol for $5 \mathrm{~min}$, rinsed in fresh $70 \%$ ethanol for a further $5 \mathrm{~min}$, in $95 \%$ ethanol for 5 min, in fresh $95 \%$ ethanol for another $5 \mathrm{~min}$, air dried, stained in buffered Gurr Giemsa ( $\mathrm{pH} \mathrm{6.8)}$ ) for $90 \mathrm{~min}$, rinsed in water, and blotted dry.

Trypsin-Giemsa methods were modified from the original method of Seabright $(1971)$ as follows. The air-dried slide was placed in $0.1 \%$ (or $0.05 \%$ ) DIFCO Bacto-trypsin for 5-10 s, rinsed once in a Coplin jar containing $50 \mathrm{ml}$ phosphate buffered saline (PBS) with two to three drops of fetal calf serum added, stained for 30$45 \mathrm{~min}$ in buffered Gurr Giemsa (pH 6.8), and air dried.

Measurement distributions between the $\mathrm{i}(\mathrm{Xq})$ cases were compared by computer analysis using a program of the Kolmogorov and Smirnov two sample test (Siegel, 1956). Mean measurements were compared to expected measurements (Paris Conference, 1971) using the $t$ test.

Sex chromatin stains for buccal smears were made by the method of Papanicolaou (Naib, 1970). Thionine stain was used for sex chromatin in tissue culture (Priest, 1969). The X-bodies were photographed and the $35 \mathrm{~mm}$ negatives projected. The nucleus and $\mathrm{X}$-body were traced on medium weight paper, cut out, and weighed to six decimal places. X-body weights were compared using the $t$ test.

\section{Case reports}

The case histories and laboratory findings of the three cases with $i(X q)$ are summarized in Table 1 . The mother and grandmother of case 3 are also included. Although they do not have $i(\mathbf{X q})$, they have other $X$ chromosome defects consisting of mosaicism for $45, \mathrm{X} /$ $46, \mathrm{XX}, \mathrm{r}(\mathrm{X})$. Abbreviated pedigrees, as well as photographs showing the phenotypes are presented in Fig. 1 to 6. Short stature and defective space-form perception were consistent clinical findings in all of the $\mathrm{i}(\mathrm{Xq})$ cases. In the two older cases, gonadal and menstrual abnormalities were present.

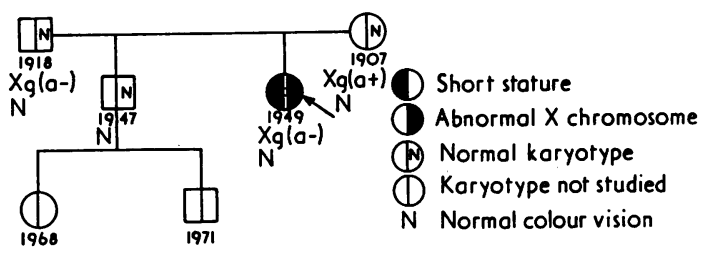

FIG. 1. Pedigree of case 1 (arrow); non-mosaic $46, \mathrm{X}, \mathrm{i}(\mathrm{Xq})^{1}$ patient.

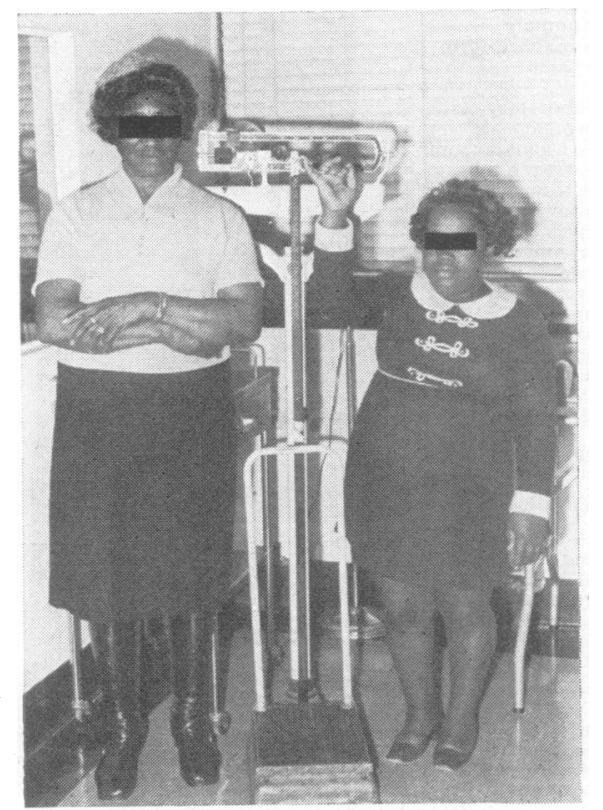

Fig. 2. Case 1 (right) and her chromosomally normal mother (left). 


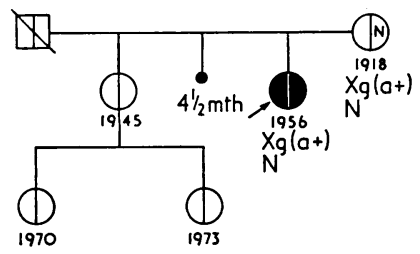

FIg. 3. Pedigree of case 2 (arrow); mosaic $45, \mathrm{X} / 46, \mathrm{X}, \mathrm{i}(\mathrm{Xq})^{2}$ patient.

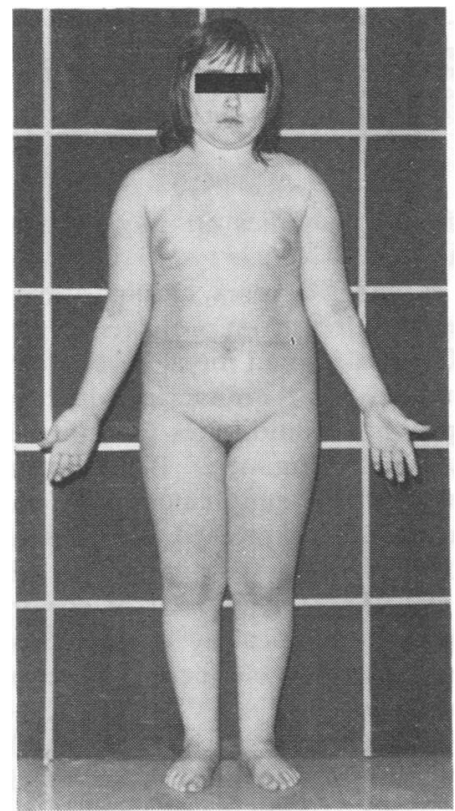

FIG. 4. Case 2 presenting many somatic features of Turner's syndrome.

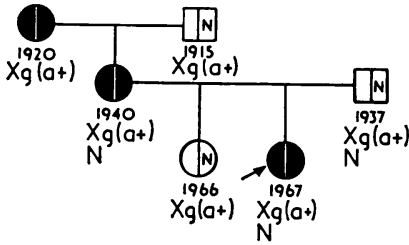

FIG. 5. Pedigree of case 3 (arrow); mosaic $45, \mathrm{X} / 46, \mathrm{X}, \mathrm{i}(\mathrm{Xq}$ ) patient. Her mother and maternal grandmother have a $45, \mathrm{X}$ / $46, X X / 46, X, r(X)$ karyotype.

\section{Results}

Tables II and III summarize studies to determine the presence of $\mathrm{i}(\mathrm{Xq})$ and abnormal $\mathrm{X}$ chromosome constitution in the reported individuals. In case 1 , only cells containing the $i(X q)^{1}$ could be demonstrated in three different tissues: peripheral

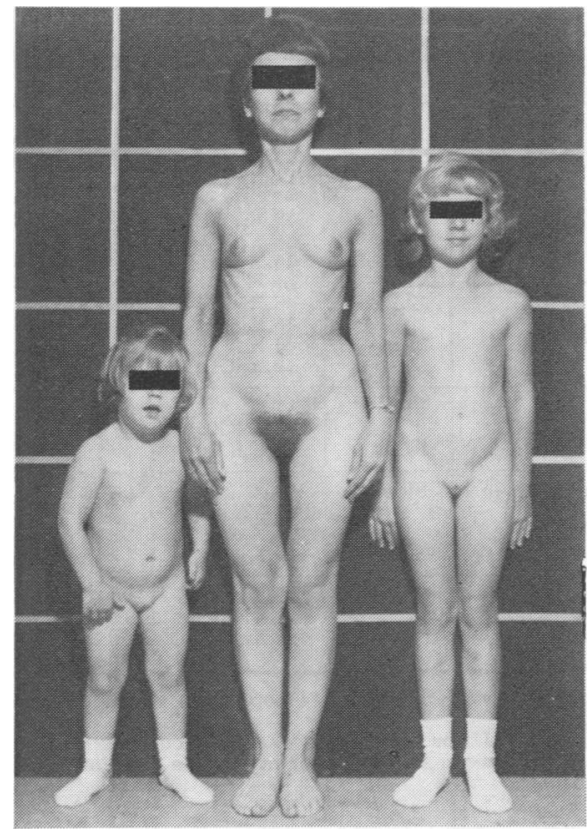

FIG. 6. Case 3 (left) exhibiting some somatic features of Turner's syndrome. Her mother and chromosomally normal sister (right) are shown.

blood, skin, and gonad cultures. Case 2, showed $45, \mathrm{X} / 46, \mathrm{X}, \mathrm{i}(\mathrm{Xq})^{2}$ mosaicism in both peripheral blood and skin, but lost 45,X cells with increasing time in culture of skin (Table III). Case 3 showed $45, \mathrm{X} / 46, \mathrm{X}, \mathrm{i}(\mathrm{Xq})^{1}$ mosaicism in peripheral blood, but only $46, \mathrm{X}, \mathrm{i}(\mathrm{Xq})^{1}$ cells in skin culture.

$\mathrm{X}$-chromatin studies from the three cases are summarized in Table IV. The non-mosaic $46, \mathrm{X}, \mathrm{i}(\mathrm{Xq})^{1}$ patient (case 1) had Barr bodies which were larger than normal (Fig. 7) in a normal percentage of cells from buccal smear, skin, and gonad cultures. Cases 2 and 3, the mosaic patients, showed larger than normal Barr bodies in normal to decreased percentages of cells, depending on the tissue examined. Quantitative studies of Barr body size are summarized in Table $\mathrm{V}$. Both types of isochromosomes were associated with larger than normal $\mathrm{X}$-bodies by quantitative assessment (weight). The $\mathrm{X}$-body weights were not significantly different between the two types of isochromosomes. When X-body weight was expressed per nuclear weight there was a significant difference between the two types of isochromosomes, but this finding was due to an unexplained difference in nuclear size between preparations from the two cases. Double structure was not a prominent 
TABLE II

CYTOGENETIC STUDIES BY TRYPSIN-GIEMSA TECHNIQUE

\begin{tabular}{|c|c|c|c|c|}
\hline Case & Tissue & $\begin{array}{c}\text { Sex } \\
\text { Chromosome } \\
\text { Identification }\end{array}$ & $\begin{array}{l}\text { Total } \\
\text { No. of } \\
\text { Cells }\end{array}$ & $\underset{(\%)}{\text { Mean }}$ \\
\hline 1 & $\begin{array}{l}\text { Blood } \\
\text { Skin* } \\
\text { Gonad* }\end{array}$ & $\begin{array}{l}46, X, \mathrm{i}(\mathrm{Xq})^{1} \\
46, \mathrm{X}, \mathrm{i}(\mathrm{Xq})^{1} \\
46, \mathrm{X}, \mathrm{X}(\mathrm{Xq})^{1}\end{array}$ & $\begin{array}{r}50 \\
100 \\
50\end{array}$ & $\begin{array}{l}100 \\
100 \\
100\end{array}$ \\
\hline 2 & $\begin{array}{l}\text { Blood } \\
\text { Skint }\end{array}$ & $\begin{array}{l}45, X \\
46, X, i(X q)^{2} \\
45, X \\
46, X, i(X q)^{2}\end{array}$ & $\begin{array}{r}8 \\
55 \\
8 \\
127\end{array}$ & $\begin{array}{r}13 \\
87 \\
6 \\
94\end{array}$ \\
\hline 3 & $\begin{array}{l}\text { Blood } \\
\text { Skin } \ddagger\end{array}$ & $\begin{array}{l}\text { 45,X } \\
46, X, i(X q)^{1} \\
46, X, i(X q)^{1}\end{array}$ & $\begin{array}{r}117 \\
88 \\
50\end{array}$ & $\begin{array}{r}57 \\
43 \\
100\end{array}$ \\
\hline Mother of case 3 & $\begin{array}{l}\text { Blood } \\
\text { Skin } \ddagger\end{array}$ & $\begin{array}{l}45, \mathrm{X} \\
46, \mathrm{X} x \\
46, \mathrm{X}, \mathrm{r}(\mathrm{X}) \\
45, \mathrm{X}\end{array}$ & $\begin{array}{r}108 \\
7 \\
4 \\
41\end{array}$ & $\begin{array}{r}91 \\
6 \\
3 \\
100\end{array}$ \\
\hline $\begin{array}{l}\text { Grandmother of } \\
\text { case } 3\end{array}$ & Blood & $\begin{array}{l}\text { 45,X } \\
46, X X \\
46, X, r(X)\end{array}$ & $\begin{array}{r}14 \\
2 \\
3\end{array}$ & $\begin{array}{l}74 \\
11 \\
15\end{array}$ \\
\hline
\end{tabular}

* Studied between four and 14 population doublings from first subculture.

$\dagger$ See Table III for karyotype evolution in culture.

\# Studied between zero and four population doublings from first subculture.

TABLE III

EVOLUTION OF $45, \mathrm{X} / 46, \mathrm{X}, \mathrm{i}(\mathrm{Xq})^{2}$ IN SKIN CULTURE OF CASE 2

\begin{tabular}{c|c|c}
\hline $\begin{array}{c}\text { Population Doublings } \\
\text { from 1st Subculture }\end{array}$ & \multicolumn{2}{|c|}{ Percentage of Cells } \\
\cline { 2 - 3 } & $45, \mathrm{X}$ & $46, \mathrm{X}, \mathrm{i}(\mathbf{X q})^{2}$ \\
\hline 3 & 13 & 87 \\
5 & 10 & 90 \\
11 & 4 & 96 \\
18 & 0 & 100 \\
\hline
\end{tabular}

TABLE IV

MEAN PERCENTAGE OF POSITIVE CELLS

\begin{tabular}{l|c|c|c|c}
\hline \multirow{2}{*}{ Case } & \multicolumn{2}{|c|}{ Buccal Smear* } & $\begin{array}{c}\text { Skin } \\
\text { Culturet }\end{array}$ & $\begin{array}{c}\text { Gonad } \\
\text { Culture }\end{array}$ \\
\cline { 2 - 5 } & Left & Right & & \\
\hline 2 & 27 & 31 & 88 & 90 \\
\hline 3 & 15 & 22 & $78 \ddagger$ & - \\
\hline Mother of case 3 & 2 & 6 & 80 & - \\
\hline Grandmother of case 3 & 4 & 3 & - & - \\
\hline
\end{tabular}

* Normal range for $46, \mathrm{XX}$ in this laboratory is $20-30$.

$\dagger$ Normal range for 46, XX in this laboratory is 75-90.

₹ Studied at 25 population doublings (at this time the karyotype was $46, X, i(X q)^{2}$ with no evidence of mosaicism for $45, X$ cells).

feature of the $\mathrm{X}$-bodies in any of the patients (Therman et al, 1974b).

In each of the $i(X q)$ cases, chromosomes $3, X$, and $\mathrm{i}(\mathrm{Xq})$ were measured from projected negatives of 25 standard Giemsa-stained metaphases after they had been re-stained with quinacrine dihydrochloride, and the specific chromosomes identified in fluorescent karyotypes (Fig. 8). Because only three chromosomes of the complement were studied, the measurements were expressed either as centromere index (CI) (Table VI) or relative to each other within the same cell (Table VII). CI of chromosomes 3 and $\mathrm{X}$ were not significantly different between the three cases, nor from the expected as defined by the Paris Conference (1971). The $\mathrm{i}(\mathrm{Xq}) \mathrm{CI}$ of cases 1 and 3 were not significantly different from each other; this type of isochromosome is defined as $\mathrm{i}(\mathrm{Xq})^{1}$. The $\mathrm{i}(\mathrm{Xq}) \mathrm{CI}$ of case 2 differed significantly as compared with the other two cases, and this

TABLE V

X-BODY SIZE IN BUCCAL SMEARS FROM TWO ISOCHROMOSOME PATIENTS AND TWO CHROMOSOMALLY NORMAL CONTROLS

Expressed as weight/cell (g); mean of 30 cells

\begin{tabular}{l|c|c|c|c}
\hline & $46, \mathrm{X}, \mathrm{i}(\mathrm{Xq})^{1}($ Case 1) & $46, \mathrm{X}, \mathrm{i}(\mathrm{Xq})^{2}$ (Case 2) & $46, \mathrm{XX}$ (Control 1) & $46, \mathrm{XX}($ Control 2) \\
\hline X-body & $0.008458 \pm 0.002014$ & $0.008794 \pm 0.002668$ & $0.004909 \pm 0.000884$ & $0.005119 \pm 0.001277$ \\
\hline Nucleus & $0.350380 \pm 0.064358$ & $0.461061 \pm 0.148022$ & $0.301250 \pm 0.043676$ & $0.302416 \pm 0.043271$ \\
\hline X-body/nucleus $\times 100$ & $2.508 \pm 0.8091$ & $1.989 \pm 0.4957$ & $1.656 \pm 0.3558$ & $1.706 \pm 0.3948$ \\
\hline
\end{tabular}

$p$ Values by $t$ test (significant differences are given in italics)

\begin{tabular}{l|c|c}
\hline & X-body & X-body/nucleus $\times 100$ \\
\hline Control 1 vs. control 2 & 0.500 & 0.500 \\
Case 1 vs. case 2 & 0.500 & $0.005-0.001$ \\
Controls 1 and 2 vs. cases 1 and 2 & $<0.001$ & $<0.001$ \\
Controls 1 and 2 vs. case 1 & & $0.005-0.001$ \\
Controls 1 and 2 vs. case 2 & & \\
\hline
\end{tabular}




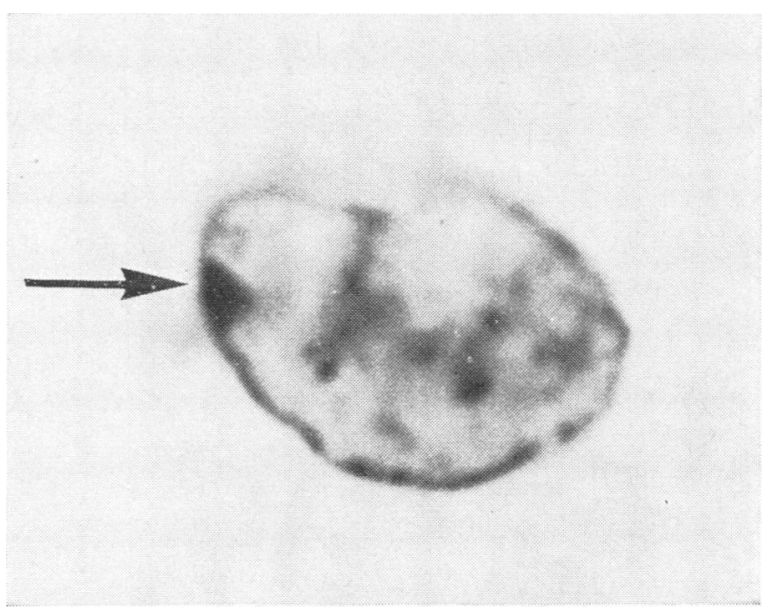

Fig. 7. Barr body (arrow) from case 1 showing large and prominent morphology.

TABLE VI

CENTROMERE INDEXES COMPARED BY NONPARAMETRIC METHOD OF KOLMOGOROV-SMIRNOV Mean of 25 metaphases for each case

\begin{tabular}{|c|c|c|c|c|c|c|c|}
\hline \multirow{2}{*}{ Chromosome } & \multirow{2}{*}{ Expected* } & \multicolumn{3}{|c|}{ Observed } & \multicolumn{3}{|c|}{ p Valuest } \\
\hline & & Case 2 & Case 1 & Case 3 & Case 2 vs. Case 1 & Case 2 vs. Case 3 & Case 1 vs. Case 3 \\
\hline 3 & 47.3 & $47.41 \pm 1.22$ & $47.80 \pm 1.01$ & $47.31 \pm 1.24$ & 0.281 & 0.994 & 0.281 \\
\hline $\mathbf{x}$ & 39.7 & $40.33 \pm 3.06$ & $39.53 \pm 2.29$ & $39.76 \pm 2.18$ & 0.281 & 0.155 & 0.906 \\
\hline $\mathrm{i}(\mathrm{Xq})^{\mathbf{1}}$ & & & $48.43 \pm 1.39$ & $48.36 \pm 0.89$ & & & 0.699 \\
\hline $\mathrm{i}(\mathrm{Xq})^{2}$ & & $45.88 \pm 2.37$ & & & 0.0002 & 0.00002 & \\
\hline
\end{tabular}

* Based on mean of measurements from three laboratories (Paris Conference, 1971).

† Significant differences are given in italics.

$\mathrm{p}=$ percent probability that distributions are the same.

TABLE VII

RELATIVE MEASUREMENTS WITHIN ONE METAPHASE COMPARED BY NONPARAMETRIC METHOD OF KOLMOGOROV-SMIRNOV

Mean of 25 metaphases for each case

\begin{tabular}{|c|c|c|c|c|c|c|}
\hline & \multirow{2}{*}{ Case 2} & \multirow{2}{*}{ Case 1} & \multirow{2}{*}{ Case 3} & \multicolumn{3}{|c|}{ p Values* } \\
\hline & & & & Case 2 vs. Case 1 & Case 2 vs. Case 3 & Case 1 vs. Case 3 \\
\hline $\begin{array}{l}\text { Total length } \\
\mathrm{i}(\mathrm{Xq})^{1 / 3} \\
\mathrm{i}(\mathrm{Xq})^{2 / 3}\end{array}$ & $1.02 \pm 0.08$ & $0.88 \pm 0.06$ & $0.97 \pm 0.08$ & 0.465 & 0.468 & 0.232 \\
\hline $\begin{array}{l}\mathrm{i}(\mathrm{Xq})^{1} / \mathrm{X} \\
\mathrm{i}(\mathrm{Xq})^{2} / \mathrm{X}\end{array}$ & $1.28 \pm 0.14$ & $1.12 \pm 0.10$ & $1.20 \pm 0.10$ & 0.247 & 0.155 & 0.78 \\
\hline $\begin{array}{l}\text { Short arm } \\
\mathrm{i}(\mathbf{X q})^{1 / X} / \mathbf{X} \\
\mathbf{i}(\mathbf{X q})^{2} / \mathbf{X}\end{array}$ & $1.43 \pm 0.20$ & $1.38 \pm 0.18$ & $1.44 \pm 0.19$ & 0.468 & 0.699 & 0.366 \\
\hline $\begin{array}{l}\text { Long arm } \\
\mathrm{i}(\mathrm{Xq})^{1} / \mathrm{X} \\
\mathrm{i}(\mathrm{Xq})^{2} / \mathrm{X}\end{array}$ & $1.16 \pm 0.16$ & $0.96 \pm 0.09$ & $1.03 \pm 0.23$ & 0.000005 & 0.006 & 0.155 \\
\hline $\begin{array}{c}\text { Centromere index } \\
\mathrm{i}(\mathbf{X q})^{1 / X} / \mathrm{X} \\
\mathrm{i}(\mathbf{X q})^{2} / \mathrm{X}\end{array}$ & $1.14 \pm 0.12$ & $1.23 \pm 0.09$ & $1.21 \pm 0.09$ & 0.006 & 0.002 & 0.994 \\
\hline
\end{tabular}

* Significant differences are given in italics.

$\mathrm{p}=$ percent probability that distributions are the same. 


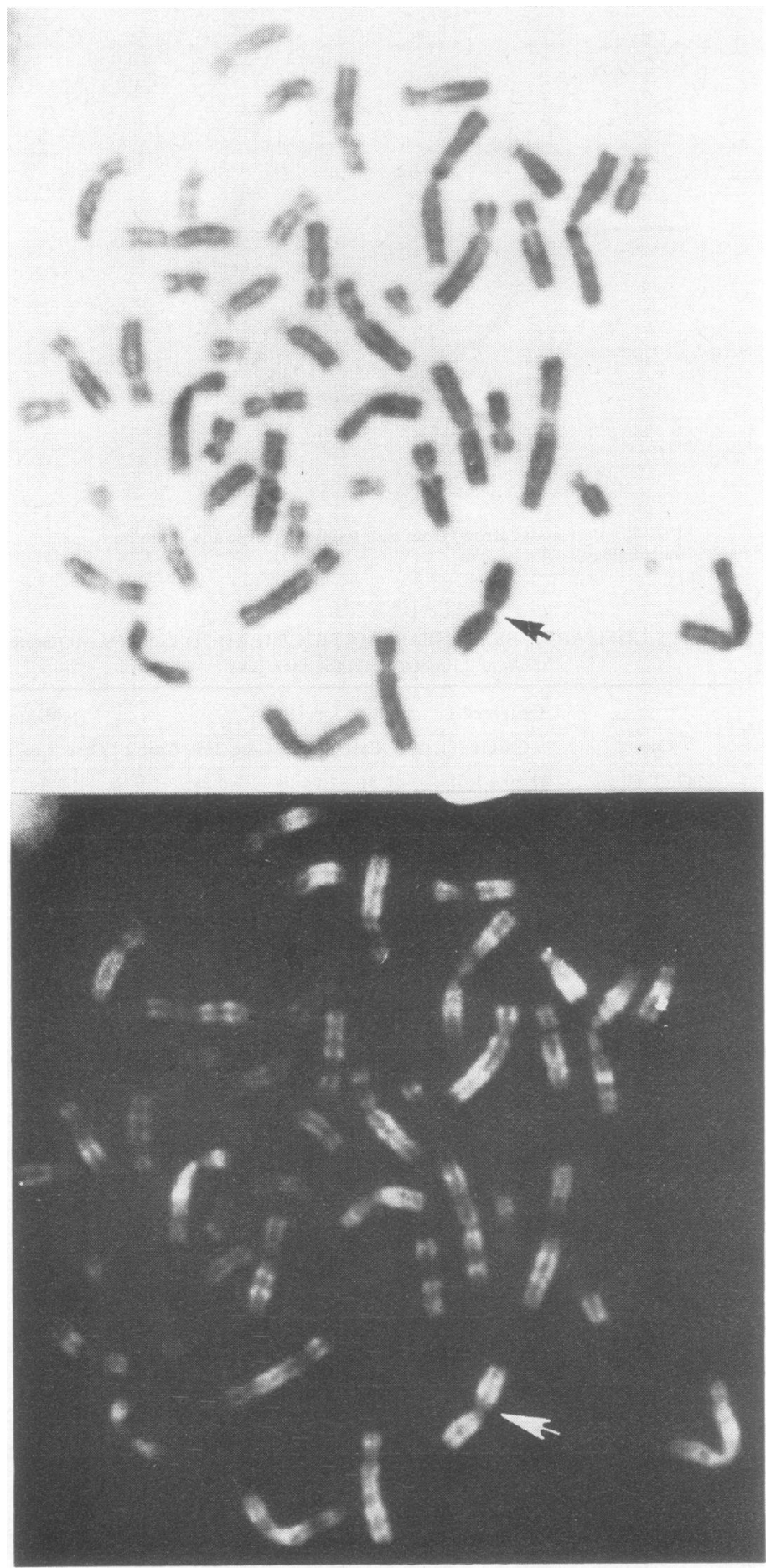

Fig. 8. Standard Giemsa stain (above) followed by quinacrine fluorescence (below) of the same metaphase illustrates an $i(X q)^{1}$ (arrow). Chromosome measurements were made on the Giemsastained chromosomes. 


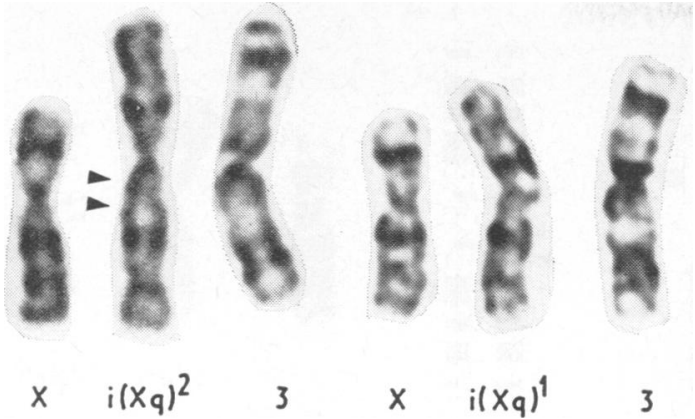

FIG. 9. Morphology by Trypsin-Giemsa technique is compared between $\mathrm{i}(\mathrm{Xq})^{2}$ (case 2) and $\mathrm{i}(\mathrm{Xq})^{1}$ (case 1 ). The $\mathrm{i}(\mathrm{Xq})^{2}$ is submetacentric and includes an extra or displaced G-band in region ql. The $i(X q)^{1}$ is metacentric and both arms show banding like the long arm of normal $X$; Paris nomenclature is $i(X)$ (qter $\rightarrow$ cen $\rightarrow$ qter).

Total length of both isochromosome types is similar to chromosome 3

type of isochromosome is defined as $\mathrm{i}(\mathrm{Xq})^{2}$. Type 1 isochromosome is relatively metacentric $(\mathrm{CI}=$ 48.4), the centromere position resembling most closely chromosomes 1 and 3 . Type 2 isochromosome is relatively submetacentric $(\mathrm{CI}=45.9)$. The relative total lengths within a metaphase (Table
VII) do not show significant differences between $\mathrm{i}(\mathrm{Xq})^{1}$ and $\mathrm{i}(\mathrm{Xq})^{2}$. Both types are similar in length to chromosome 3 and longer than normal $X$ within the same cell. The long arm in $\mathrm{i}(\mathrm{Xq})^{2}$, relative to long arm of normal $X$, is significantly longer than in $\mathrm{i}(\mathrm{Xq})^{1}$. Figure 9 illustrates these differences between $\mathrm{i}(\mathrm{Xq})^{1}$ and $\mathrm{i}(\mathrm{Xq})^{2}$ stained by the Trypsin-Giemsa technique and compared with chromosome 3 and normal $X$ in the same cell. Note that $\mathbf{i}\left(\mathrm{Xq}^{2}\right)^{2}$ has an extra G-band in the region ql (see also Fig. 11). Figure 10a shows a C-banded metaphase including an $\mathrm{i}(\mathrm{Xq})^{2}$ with an extra C-band in the region $\mathrm{ql}$ (arrow). In Fig. $10 \mathrm{~b}, \mathrm{i}(\mathrm{Xq})^{2}$ with two C-bands is compared with $\mathrm{i}(\mathrm{Xq})^{1}$ with single C-band.

\section{Discussion}

Morphological differences in isochromosomes for the long arm of the human $\mathrm{X}$ chromosome are interesting both for delineating the phenotype associated with abnormal $\mathrm{X}$ chromosomes and for an understanding of isochromosome formation. Because $\mathrm{i}(\mathrm{Xq}) \mathrm{s}$ are generally inactivated (late

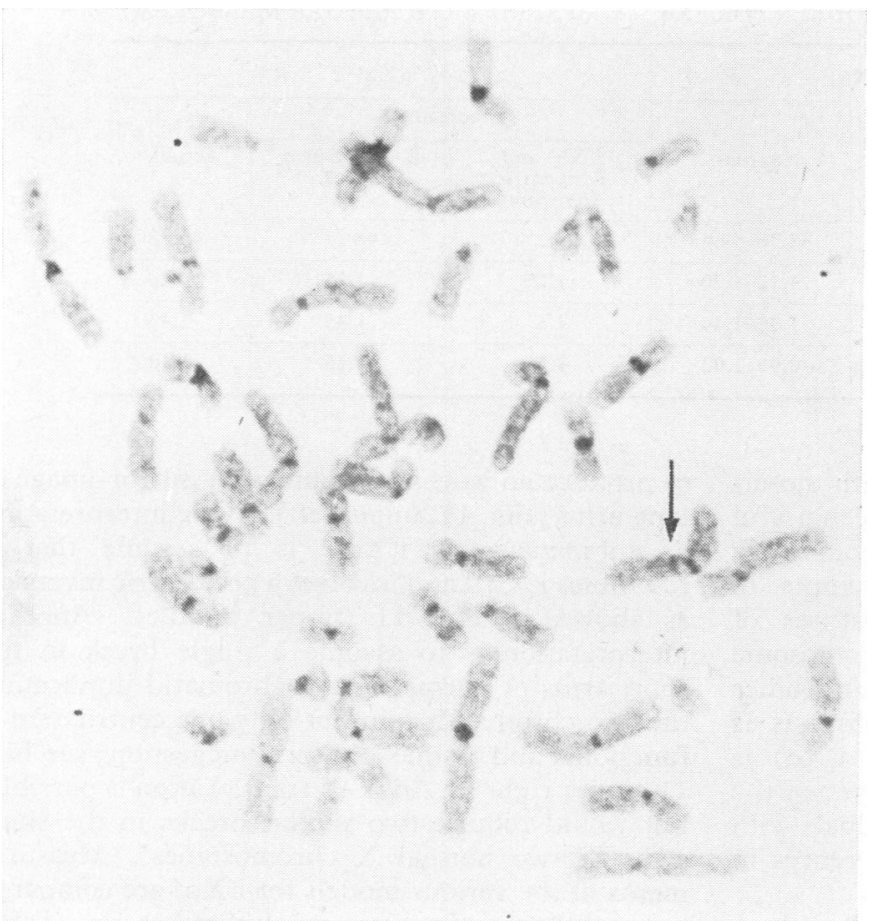

FIg. 10a. An $\mathrm{i}(\mathrm{Xq})^{2}$ with double C-band (arrow) is shown in a metaphase from case 2 .

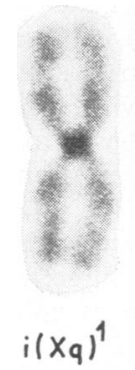

$$
i\left(x_{q}\right)^{2}
$$

FIG. 10b. The single C-band of $i(X q)^{1}$ from case 1 is compared to the double C-band from case 2 . 


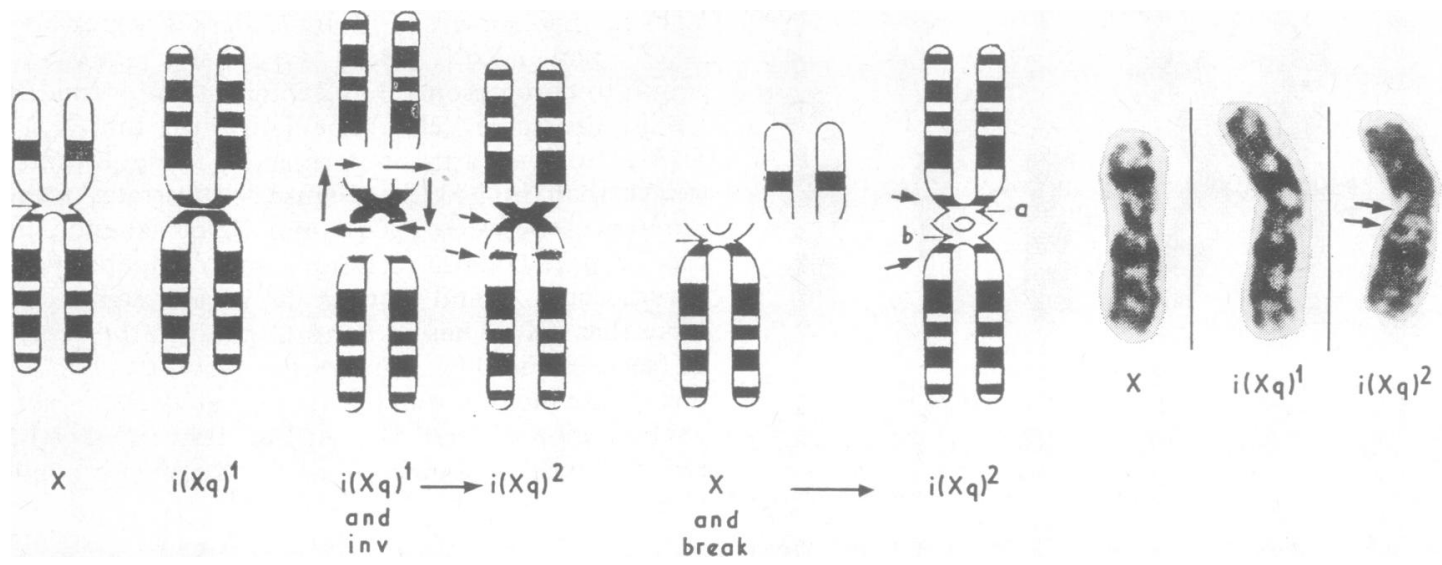

FIG. 11. Models for the formation of $\mathbf{X}$ long arm isochromosome types 1 and 2 are presented on the left. They are approximate with respect to length measurements. Photomicrographs of Trypsin-Giemsa stained chromosomes $\mathrm{X}$, $\mathrm{i}(\mathrm{Xq})^{1}$, and $\mathrm{i}(\mathrm{Xq})^{2}$ are shown on the right. $i(X q)^{1}$ is $i(X)\left(q t e r \rightarrow c e n \rightarrow q\right.$ ter) as shown. A pericentric inversion of $i(X q)^{1}$ could produce $i(X q)^{2}$ with extra $G-b a n d$ in the region of ql, and extra C-band as well (C-banding not illustrated). Break point in the 'upper arm' of the $\mathrm{i}(\mathrm{Xq})^{1}$ is in region $\mathrm{q} 13$; break point in lower arm is in region q11, as shown in the model. The segment lying between these bands is inverted. Alternatively, and more simply, a single break in region p11 not far from the centromere of normal $X$, followed by chromatid duplication and joining of chromatids from one side of the break could also explain $\mathbf{i}(\mathbf{X q})^{2}$. Centromere a would be visible (and functional) while centromere b would not. However, the C-bands of both centromere regions would be visible and separated by the distance from a to b. A displaced G-band would appear in region ql. The Paris classification (1971) of this model is X(qter $\rightarrow$ cen $\rightarrow$ p11::p11 $\rightarrow$ cen $\rightarrow$ qter).

TABLE VIII

MEASUREMENTS OF THEORETICAL MODELS FOR $\mathrm{i}(\mathrm{Xq})$, COMPARED WITH ACTUAL MEASUREMENTS

\begin{tabular}{|c|c|c|c|c|c|}
\hline & \multicolumn{2}{|c|}{$i(\mathbf{X q})^{1}$} & \multicolumn{3}{|c|}{$i(\mathbf{X q})^{2}$} \\
\hline & \multirow[b]{2}{*}{ Theoretical } & \multirow[b]{2}{*}{ Actual } & \multicolumn{2}{|c|}{ Theoretical } & \multirow[b]{2}{*}{ Actual } \\
\hline & & & $\begin{array}{l}\mathrm{i}(\mathrm{Xq}) \text { and } \\
\text { Pericentric } \\
\text { Inversion }\end{array}$ & $\underset{\substack{\text { Break } \\
\text { X-Short-arm }}}{ }$ & \\
\hline Centromere Index & 50 & $48.36-48.43$ & 45 & 46 & 45.88 \\
\hline Total length $\mathrm{i}(\mathrm{Xq}) / \mathrm{X}$ & 1.2 & $1.12-1.20$ & 1.25 & 1.25 & 1.28 \\
\hline Short $\operatorname{arm} i(X q) / X$ & 1.45 & $1.38-1.44$ & 1.4 & 1.45 & 1.43 \\
\hline Long Arm i $(X q) / X$ & 1.0 & $0.96-1.03$ & 1.15 & 1.15 & 1.16 \\
\hline
\end{tabular}

replicating) and may also be associated with mosaicism (Muldal et al, 1963), they have not been useful for mapping specific genes on the $\mathrm{X}$ chromosome (Polani et al, 1970). Nevertheless, attempts to correlate short stature and somatic features of Turner's syndrome with absence of $\mathrm{X}$ chromosome short arm have been based to some extent on studies of human $\mathrm{i}(\mathrm{Xq}) \mathrm{s}$ (Ferguson-Smith, 1965). It is now clear that specific morphology of $i(X q)$ is important in such correlative studies. Some of the reported phenotypic differences in individuals with $\mathbf{i}(\mathbf{X q})$ may be due to morphological differences in the isochromosomes.

The best interpretation of $\mathrm{i}(\mathrm{Xq})^{1}$ described here is to assume transverse breakage of the centromere to produce an isochromosome with mirror-image $\mathrm{X}$ long arms (Fig. 11, upper left). One interpretation of submetacentric $i(X q)^{2}$ is to assume that it resembles $\mathrm{i}(\mathrm{Xq})^{1}$ and involves a pericentric inversion as shown in Fig. 11 (upper middle). Another interpretation is to assume a single break in the short arms of normal $\mathrm{X}$; on chromatid duplication the two chromatids join but only one centromere is functional and visible (Editors' suggestion; see Fig. 11, upper right). An X-X translocation is possible, but would require two similar breaks in the short arms of two normal X chromosomes. Measurements of the various models for $\mathrm{i}(\mathrm{Xq})$ are compared to actual chromosome measurements in Table VIII; the fits are quite close. Ruthner and Golob 
TABLE IX

SUMMARY OF DIFFERENT TYPES OF $\mathrm{i}(\mathrm{Xq})$ OR X DUPLICATION REPORTED WITH BANDING STUDIES

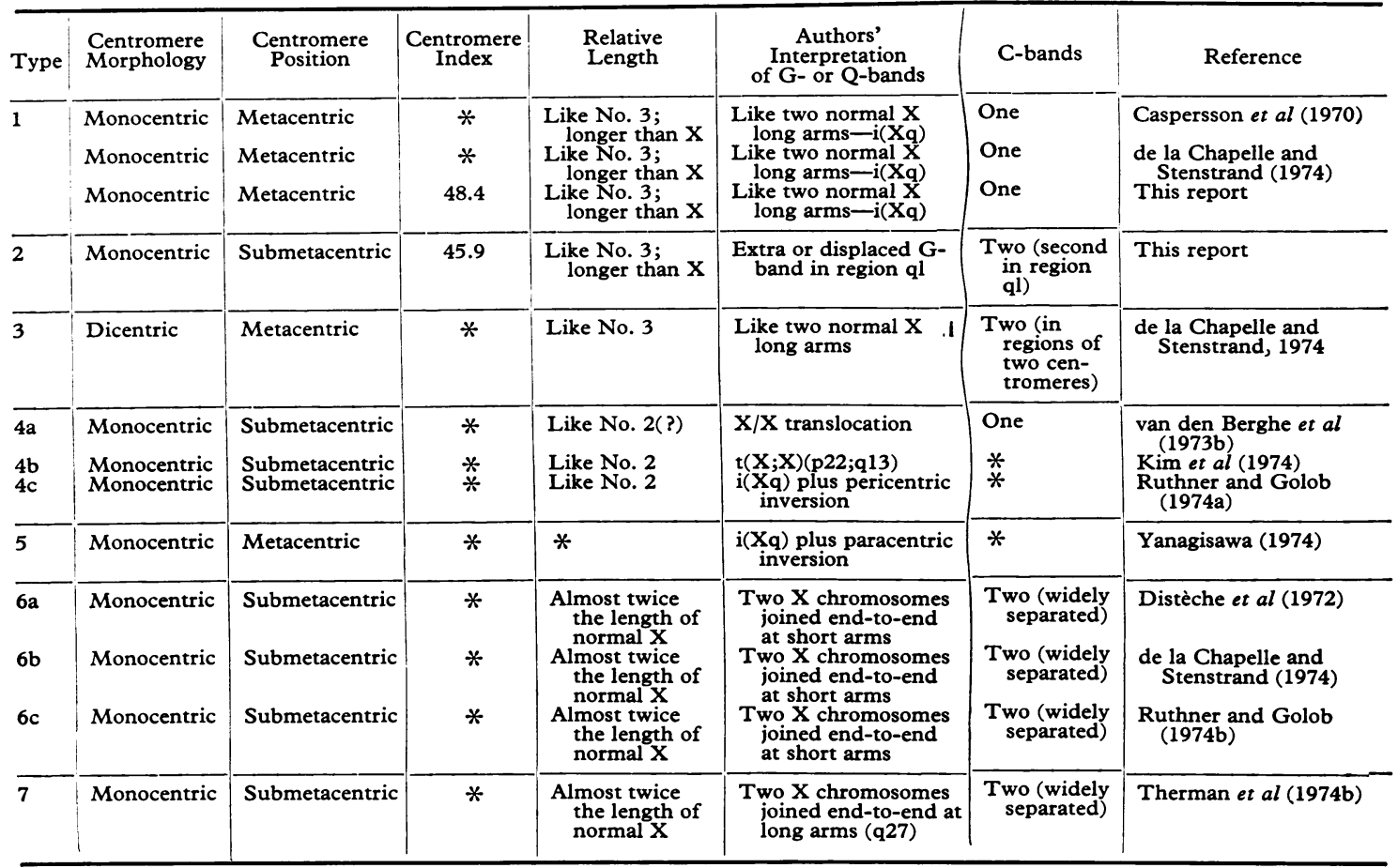

* Not determined

(1974a) interpreted their submetacentric isochromosome to be an $\mathrm{i}(\mathrm{Xq})$ with pericentric inversion. However, their isochromosome resembled a number 2 while the $\mathrm{i}(\mathrm{Xq})^{2}$ here has a total length closely resembling a number 3 . Whether the $\mathrm{X}$ isochromosome of Ruthner and Golob also had double $\mathrm{C}$-bands is not known. The $\mathrm{i}(\mathrm{Xq})$ described by de la Chapelle and Stenstrand (1974) with double C-bands was metacentric and therefore different in morphology from $\mathrm{i}(\mathrm{Xq})^{2}$ described here.

Of the two possible interpretations presented for $\mathrm{i}(\mathrm{Xq})^{2}$ described in this report, a single short arm break hypothesis is attractive because it is the simplest; it does not explain why the resulting chromosome with long-arm and some short-arm duplication appears monocentric rather than dicentric. However, some cases of X-X translocations or $\mathrm{X}$ duplications now reported with banding studies suggest that a second centromere need not be visible morphologically (Distèche $e t$ al, 1972; de la Chapelle and Stenstrand, 1974; Ruthner and Golob, 1974b; Therman et al, 1974b).
A unifying hypothesis for the formation of various types of $\mathrm{X}$ long- and short-arm duplications could assume that breaks occur at different points along the chromosome, including at or very near the centromere. The latter would produce $i(X q)^{1}$ which is $(\mathrm{X})$ (qter $\rightarrow$ cen $\rightarrow$ qter); this type is probably the more common one. Single breaks at other points along $\mathrm{X}$ chromosome arms followed by chromatid duplication and joining of chromatids from one side of the break could explain the case of $\mathrm{i}(\mathrm{Xq})^{2}$ reported here, as well as other varieties of $X q$ and $X p$ duplications reported since banding and summarized in Table IX, where chromosomes with the same morphology, from different reports, are assigned the same type number. Chromosomes that may be similar are assigned the same type number but are sublettered. The listing is tentative because of incomplete information or the possibility of alternative interpretations. One difficult problem is to determine if the abnormal $\mathrm{X}$ chromosomes involve rearrangements between one or two $\mathrm{X}$ chromosomes. Terminology is also confusing until this latter problem is resolved. 
Barlow (1972) stated that the proportion of 45,X cells increases with time in culture. Chromosome evolution in skin culture of the $45, \mathrm{X} / 46, \mathrm{X}, \mathrm{i}(\mathrm{Xq})^{2}$ described here suggests the opposite; in other words, 45,X cells were lost. The case of $45, \mathrm{X} /$ $46, X, i(X q)^{1}$ reported here is non-informative, since no $45, \mathrm{X}$ cells were ever demonstrated in skin culture.

Quantitative studies of X-body size (weight) indicate that the two types of $i(X q)$ reported here do not produce different sized X-bodies; they both produce larger than normal X-chromatin. However, the increase is more than three times what would be expected from the relative length increase of $i(X q)$ compared with normal $X$. These findings have several possible explanations: first, the standard deviation for our X-body measurements is large and we do not know how much variation there is between patients, both $\mathrm{i}(\mathrm{Xq})$ and $\mathrm{XX}$; we have studied only two in each category. Secondly, if these observations are confirmed in more cases, they may represent a different degree of interphase condensation between late replicating (inactivated) $\mathbf{i}(\mathbf{X q})$ and $X$. Thirdly, again if these observations are confirmed in more cases, another explanation could be that all of the late replicating, normal $X$ in $\mathrm{XX}$ females does not form an X-body (a portion of the short arm might not participate), while all of the late replicating $i(X q)$ forms an $X$-body.

Our patients, of both $\mathrm{i}(\mathrm{Xq})$ types and with or without mosaicism, consistently showed short stature as well as perceptual problems, and the two older patients also had gonadal abnormalities. The non-mosaic $\mathrm{i}(\mathrm{Xq})^{1}$ had no other somatic malformation of Turner syndrome. Variability of other somatic malformations was present in the $45, \mathrm{X} /$ $46, \mathrm{X}, \mathrm{i}(\mathrm{Xq})^{1}$ and $45, \mathrm{X} / 46, \mathrm{X}, \mathrm{i}(\mathrm{Xq})^{2}$ patients. Some of the variability in somatic features of Turner's syndrome, other than short stature and perceptual problems, could be accounted for by differences in $\mathrm{i}(\mathrm{Xq})$ morphology. Otherwise, the clinical findings in our patients do not contradict hypotheses (de la Chapelle et al, 1972; van den Berghe et al, 1973a) supported by recent banding studies of $i(X q) s:$ (1) controlling factors for gonadal development are carried in both $\mathrm{Xp}$ and $\mathrm{Xq}$; (2) $\mathrm{Xp}$ rather than $\mathrm{Xq}$ is required for normal growth. The $i(X q)^{2}$ reported here may imply that $\mathrm{Xp} 1$ region near the centromere does not determine normal growth, if the single break hypothesis is correct for formation of $\mathbf{i}(\mathbf{X q})^{2}$. The morphological differences of $X$ long arm isochromosomes or duplications summarized in Table IX complicate their use for studying the effect of $\mathrm{X}$ chromosome structure on phenotype unless the differences are clearly defined. In addition to banding studies by all available methods, it is useful to include the following studies in reports of new abnormal $\mathrm{X}$ chromosomes: (1) centromere index; (2) total length relative to selected chromosomes in the complement, such as normal $X$ and one other reference chromosome (number 3); (3) length of long and short arms relative to the same reference chromosomes.

This project was supported by grants from The National Institutes of Health: GM 19268, RR 39, and HD 06416; and a programme grant (C-186) from National Foundation-March of Dimes.

\section{REFERENCES}

Arrighi, F. E., and Hsu, T. C. (1971). Localization of heterochromatin in human chromosomes. Cytogenetics, 10, 81-86.

Barlow, P. W. (1972). Differential cell division in human $X$ chromosome mosaics. Humangenetik, 14, 122-127.

Berghe, H. van den, Fryns, J. P., and Devos, F. (1973a). 46,XXip karyotype in a woman with normal stature and gonadal dysgenesis without other congenital anomalies. Humangenetik, 20, 163-166.

Berghe, H. van den, Fryns, J. P., and Soyez, C. (1973b). X/X translocation in a patient with Turner's syndrome. Humangenetik, 20, 377-380.

Caspersson, T., Lindsten, J., and Zech, L. (1970). The nature of structural $\mathbf{X}$ chromosome aberrations in Turner's syndrome as revealed by quinacrine mustard fluorescence analysis. Hereditas, Genetiskt Arkiv, 66, 287-292.

Chapelle, A. de la, Schröder, J., and Pernu, M. (1972). Isochromosome for the short arm of X, a human 46, XXpi syndrome. Annals of Human Genetics, 36, 79-87.

Chapelle, A. de la and Stenstrand, K. (1974). Dicentric human X chromosomes. Hereditas, Genetiskt Arkiv, 76, 259-268.

Distèche, C., Hagemeijer, A., Frederic, J., and Progneaux, D. (1972) An abnormal large human chromosome identified as an end-toend fusion of two X's by combined results of the new banding techniques and microdensitometry. Clinical Genetics, 3, 388-395.

Ferguson-Smith, M. A. (1965). Karyotype-phenotype correlations in gonadal dysgenesis and their bearing on the pathogenesis of malformations. Fournal of Medical Genetics, 2, 142-155.

Kim, H. J., Hsu, L. Y. F., and Hirschhorn, K. (1974). Familial $\mathrm{X} / \mathrm{X}$ translocation: $\mathrm{t}(\mathrm{X} ; \mathrm{X})(\mathrm{p} 22 ; \mathrm{q} 13)$. Cytogenetics and Cell Genetics, 13, 454-464.

Muldal, S., Gilbert, C. W., Lajtha, L. G., Lindsten, J., Rowley, J., and Fraccaro, M. (1963). Tritiated thymidine incorporation in an isochromosome for the long arm of the $\mathbf{X}$ chromosome in man. Lancet, 1, 861-863.

Naib, Z. M. (1970). Exfoliative Cytopathology, pp. 372-373. Little, Brown and Company, Boston.

Paris Conference (1971). Standardization in human cytogenetics. Birth Defects: Original Article Series, 8, pt. 7, 1972. The National Foundation-March of Dimes, New York.

Polani, P. E., Angell, R., Giannelli, F., de la Chapelle, A., Race, R. R., and Sanger, R. (1970). Evidence that the $\mathrm{Xg}_{\mathbf{g}}$ locus is inactivated in structurally abnormal $\mathrm{X}$ chromosomes. Nature, 227, 613-616.

Priest. J. H. (1969). Cytogenetics, pp. 193-195. Lea and Febiger, Philadelphia.

Ruthner, U. and Golob, E. (1974a). Identification of a large submetacentric $X$ chromosome as pericentric inversion of an isochromosome of the long arm. Humangenetik, 22, 171-175.

Ruthner, U. and Golob, E. (1974b). Fusion of the short arms of one $\mathbf{X}$ chromosome in a patient with gonadal dysgenesis. Humangenetik, 24, 159-160.

Seabright, M. (1971). A rapid banding technique for human chromosomes. Lancet, 2, 971-972.

Siegel, S. (1956). Nonparametric Statistics, pp. 47-60. McGrawHill, New York.

Sumner, A. T., Evans, J. H., and Buckland, R. A. (1971). A new 
technique for distinguishing between human chromosomes. Nature New Biology, 232, 31-32.

Therman, E., Sarto, G. E., and Patau, K. (1974a). Center for Barr body condensation on the proximal part of the human Xq: a hypothesis. Chromosoma, 44, 361-366.
Therman, E., Sarto, G., and Patau, K. (1974b). Apparently isodicentric but functionally monocentric $X$ chromosome in man. American fournal of Human Genetics, 26, 83-92.

Yanagisawa, S. (1973). Isochromosome $\mathrm{X}$ associated with paracentric inversion. Lancet, 2, 1448. 